\title{
MODAL INTELEKTUAL, KEPEMILIKAN INSTITUSIONAL TERHADAP PROFITABILITAS DAN NILAI PERUSAHAAN
}

\author{
Nurramayuningsih \\ nurramayuningsih@gmail.com \\ Mujibah A. Sufyani \\ Universitas Pasundan \\ Jl. Tamansari No. 6-8, Bandung 40116
}

diterima: 20/12/2019; direvisi: 26/1/2020; disetujui: 28/4/2020

\begin{abstract}
Knowledge and intangible assets become the important source of competitive advatage for company (knowledgw-based economy). The study aims was to investigate the effect of intellectual capital, institutional ownership to profitability and firm value. Sample used were 6 manufacturing companies of sub sectors consumer goods industry listed on the Indonesia Stock Exchange from 2012 to 2017, with purposive sampling, secondary data, and panel data regression analysis. The results indicated that simultaneous intellectual capital and institutional ownership affected financial performance. Partially intellectual capital had a positive and significant effect on financial performance, but institutional ownership did not have significant effect. Financial performance has a positive and significant effect on firm value. Intelectual capital had an important roles to increase performance and value of the firm.
\end{abstract}

Keywords: intellectual capital; institustional ownership; financial performance; company value; panel data regression

\begin{abstract}
Abstrak
Pengetahuan dan aktiva tidak berwujud saat ini menjadi sumber daya yang penting untuk keunggulan bersaing suatu perusahaan (knowledge-based economy). Tujuan penelitian ini adalah untuk mengetahui pengaruh modal intelektual dan kepemilikan institusional terhadap profitabilitas dan nilai perusahaan. Sampel yang digunakan sebanyak 6 perusahaan manufaktur sub sektor industri barang konsumsi yang terdaftar di Bursa Efek Indonesia periode 2012 - 2017, dengan purposive sampling, data sekunder, dan analisis regresi data panel. Hasilnya menunjukkan bahwa secara simultan modal intelektual dan kepemilikan institusional berpengaruh terhadap kinerja keuangan. Secara parsial modal intelektual berpengaruh positif dan signifikan terhadap kinerja keuangan, sedangkan kepemilikan institusional tidak berpengaruh signifikan. Kinerja keuangan berpengaruh positif dan signifikan terhadap nilai perusahaan. Modal intelektual memiliki peran penting untuk meningkatkan kinerja dan nilai perusahaan.
\end{abstract}

Kata Kunci: modal intelektual; kepemilikan institusional; kinerja keuangan; nilai perusahaan; regresi data panel 


\section{PENDAHULUAN}

Kegiatan ekonomi saat ini mengalami pertumbuhan dan persaingan yang semakin kuat. Indonesia termasuk salah satu negara yang berkembang di dunia, hal ini terbukti dengan adanya pembangunan di segala bidang termasuk pembangunan sektor ekonomi. Perekonomian di Indonesia yang semakin membaik menyebabkan timbulnya keinginan bagi para pengusaha untuk mengelola perusahaannya di Indonesia. Pengukuran perkembangan suatu negara dapat diukur dengan mengetahui perkembangan pasar modal. Pasar modal adalah pertemuan antara pihak yang memiliki kelebihan dana dengan pihak yang membutuhkan dana dengan cara memperjualbelikan sekuritas (Tandelilin, 2010). Pasar modal memiliki dua fungsi bagi perekonomian suatu negara, yaitu sebagai sarana pendanaan bagi perusahaan untuk mendapatkan modal dari masyarakat sebagai investor yang mana dana ini akan digunakan untuk melakukan pengembangan usaha. Kedua, sarana bagi masyarakat untuk berinvestasi, ikut andil dalam perkembangan suatu perusahaan dengan menanamkan modal pada instrumen keuangan seperti obligasi, saham, reksa dana, dan lain-lain. Bagi perusahaan pasar modal merupakan alternatif sebagai penambahan pendanaan dalam kegiatan operasional yang berguna untuk meningkatkan pendapatan perusahaan dan akhirnya dapat memberikan kemakmuran dan kesejahteraan masyarakat. Keuntungan yang didapat oleh masyarakat dengan cara membeli saham perusahaan tersebut.

Nilai perusahaan dapat dicerminkan dari harga saham. (Brigham \& Houston, 2019) menunjukkan beberapa pendekatan analisis rasio dalam penilaian market value, terdiri dari pendekatan price earning ratio (PER), price book value ratio (PBV), market book ratio (MBR), dividend yield ratio, dan dividend payout ratio (DPR). Proksi yang digunakan dalam penelitian ini adalah PER karena menggambarkan besarnya perbandingan antara harga pasar saham (market price per share) dengan laba per lembar saham (earning per share/EPS) (Fahmi, 2015).

Tingkat kepercayaan investor terhadap keuntungan masa depan melalui modal yang ditanamkan di perusahaan dapat dilihat melalui harga saham. Gambar 1 menunjukkan data perkembangan harga saham 3 sektor nasional di Bursa Efek Indonesia (BEI) periode 20122017. Semua sektor mengalami fluktuasi harga saham, namun sektor manufaktur memiliki kecenderungan menurun lebih besar dibandingkan sektor lain.

Perubahan harga saham sektor manufaktur periode 2012-2017 ditunjukkan pada Gambar 2. Sektor industri barang konsumsi memiliki harga saham yang cenderung menurun setiap tahun yang akan mempengaruhi penilaian investor, calon investor, dan pelaku pasar terhadap pertumbuhan perusahaan. Industri barang konsumsi terbagi menjadi beberapa sub sektor yaitu makanan dan minuman, rokok, farmasi, kosmetik, perlengkapan rumah tangga, dan lainnya.
Fenomena penurunan sub sektor industri barang konsumsi, dimulai akhir tahun 2017 yaitu kinerja keuangan HMSP dan UNVR mengalami penurunan, sehingga menurunkan harga saham. Penurunan nilai kapitalisasi pasar di sub sektor barang konsumsi juga disebabkan kenaikan bahan baku, mengakibatkan laba bruto perusahaan lebih rendah dibandingkan dengan sebelumnya (keuangan.com). Pada dasarnya, perkembangan laba akan sangat berpengaruh terhadap penentuan nilai perusahaan. Selain berkaitan dengan harga saham yang ditawarkan, investor akan mempertimbangkan perkembangan laba perusahaan melalui nilai PER.

Berbagai model dan pendekatan dapat digunakan dalam menilai kewajaran harga saham. Salah satu analisis fundamental yang digunakan adalah PER, menunjukkan rasio dari harga saham terhadap earning (Hartono, 2015). PER memungkinkan investor menghitung berapa kali (multiplier) nilai earning yang tercermin dalam harga suatu saham. Pendekatan ini diharapkan akan membantu investor dalam menentukan keputusan yang tepat dalam membeli, menahan ataupun menjual saham (Tandelilin, 2010).

Gambar 3 menunjukkan rata-rata PER perusahaan manufaktur sub sektor barang konsumsi yang terdaftar di BEI tahun 2012 -2017. Peningkatan nilai PER dapat disebabkan karena penurunan EPS yang jumlahnya lebih kecil dibandingkan harga saham. PER yang lebih tinggi menunjukkan bahwa pasar bersedia membayar lebih terhadap laba, serta memiliki harapan tinggi terhadap masa depan perusahaan sehingga bersedia untuk menghargainya dengan harga yang lebih tinggi.

Kinerja keuangan adalah suatu analisis yang dilakukan untuk melihat sejauh mana suatu perusahaan telah melaksanakan dengan menggunakan aturan-aturan pelaksanaan keuangan secara baik dan benar (Fahmi, 2015). Rasio profitabilitas merupakan rasio untuk menilai kemampuan perusahaan dalam mencari keuntungan. Rasio ini juga memberikan ukuran tingkat efektivitas manajemen suatu perusahaan. Hal ini ditunjukkan oleh laba yang dihasilkan dari penjualan dan pendapatan investasi. Semakin baik rasio profitabilitas maka semakin baik menggambarkan kemampuan tingginya perolehan keuntungan perusahaan (Kasmir, 2015).

Rasio profitabilitas terdiri dari (1) profit margin, (2) return on investment (ROI) atau return on assets (ROA), (3) return on equity (ROE), (4) earning per share (EPS), dan (5) rasio pertumbuhan. ROA digunakan oleh manajemen perusahaan untuk mengukur efektivitas keseluruhan operasi perusahaan. Peneliti menggunakan ROA dengan pertimbangan lebih komprehensif dalam mengukur tingkat pengembalian secara keseluruhan baik dari hutang maupun modal. ROA dapat mengukur kemampuan perusahaan dalam menghasilkan keuntungan operasi dengan total aktiva yang ada. Semakin tinggi nilai ROA, maka akan semakin tinggi pula minat dan kepercayaan investor (Diaz \& Jufrizen, 
2014). Selain itu, semakin tinggi rasio ini maka semakin baik produktivitas aset dalam memperoleh keuntungan bersih. Hal ini selanjutnya akan meningkatkan daya tarik perusahaan kepada investor sehingga menjadikan perusahaan tersebut semakin diminati oleh investor, karena tingkat pengembalian atau deviden akan semakin besar. Hal ini juga akan berdampak pada harga saham dari perusahaan tersebut di pasar modal yang akan semakin meningkat. Maka hal ini akan berpengaruh terhadap harga saham perusahaan dan nilai perusahaan. Gambar 4 adalah rata-rata kinerja keuangan dengan menggunakan rasio profitabilitas dengan proksi ROA pada perusahaan manufaktur sub sektor industri barang konsumsi yang terdaftar di BEI periode 2012 - 2017.

ROA pada perusahaan manufaktur sub sektor industri barang konsumsi yang terdaftar di BEI periode 2012-2017 berfluktuasi dan cenderung meningkat. Ada beberapa faktor yang mempengaruhi kinerja keuangan, peneliti menggunakan modal intelektual dan kepemilikan institusional. Modal intelektual merupakan aset dan sumber daya non-tangible perusahaan untuk menciptakan stakeholder value. Kepemilikan institusional digunakan sebagai faktor pengawasan terhadap perusahaan dan sebagai pertimbangan kepemilikan (owner considerations).

Modal intelektual di Indonesia mulai berkembang terutama setelah munculnya PSAK No, 19 (revisi 2010) tentang aktiva tak berwujud walaupun tidak dinyatakan secara eksplisit. Aset tak berwujud adalah aset non moneter yang teridentifikasi tanpa wujud fisik. Aset tak berwujud digunakan dalam menghasilkan atau menyerahkan barang dan jasa yang kemudian disewakan kepada pihak lainnya atau untuk tujuan administratif. Pada paragraf 09 PSAK No. 19 tentang aktiva tidak berwujud disebutkan terdiri dari pengetahuan, teknologi, lisensi, hak kekayaan intelektual, implikasi sistem baru, pengetahuan mengenai pasar dan merek dagang. Modal intelektual yang tinggi disebabkan perusahaan mampu mengelola dan memanfaatkan pengetahuan sehingga memiliki keunggulan kompetitif dan kemampuan daya saing dalam bisnis. Data rata-rata modal intelektual dengan menggunakan perhitungan (value added intelectual coefficient) perusahaan manufaktur sub sektor industri barang konsumsi yang terdaftar di Bursa Efek Indonesia (BEI) pada periode 2012-2017 ditunjukkan pada Gambar 5.

VAICTM pada perusahaan manufaktur sub sektor industri barang dan konsumsi yang terdaftar di BEI periode 2012-2017 berfluktuasi. Upaya pengenalan dan pemanfaatan intellectual capital akan membantu perusahaan lebih efisien, efektif, produktif, dan inovatif, sehingga meningkatkan kinerja dengan harapan kepercayaan pihak luar (stakeholder) dan terhadap return saham meningkat.

Hasil penelitian (Nuryaman, 2015), (Yovita \& Amrania, 2018) menyatakan bahwa modal intelektual berpengaruh positif terhadap profitabilitas. Profitabilitas berperan sebagai variabel antara modal intelektual dan nilai perusahaan. Hasil penelitian (Marzban et al., 2014), (Darabi et al., 2012) menunjukkan bahwa modal intelektual memiliki hubungan dengan indikator kualitas laba. Selanjutnya (Parast, Lella Zarat Dakhely; Delkhak, 2013) menyatakan bahwa modal intelektual memiliki hubungan dengan stabilitas laba. (Nurhayati, 2017), (Baroroh, 2013), (Agustina et al., 2015) menyatakan bahwa modal intelektual berpengaruh signifikan terhadap kinerja keuangan yang diukur dengan profitabilitas.

Hubungan agensi timbul ketika satu orang atau lebih mempekerjakan orang lain (principal) atau karyawan (agency) untuk dapat memberikan suatu jasa dan kemudian mendelegasikan wewenangnya terhadap agen. Manajer sebagai pengelola akan lebih banyak mengetahui tentang keadaan perusahaan dibandingkan pemegang saham, sehingga manajer mempunyai kewajiban memberikan informasi terhadap pemilik. Informasi yang disampaikan terkadang tidak sesuai dengan keadaan sebenarnya. Permasalahan agensi dapat memicu terjadinya biaya keagenan.

Biaya keagenan dapat ditekan dengan adanya kepemilikan institusional. Kepemilikan institusional dianggap dapat memonitor kinerja manajemen. Kepemilikan institusional yang tinggi juga akan menghasilkan upaya-upaya pengawasan yang lebih intens sehingga dapat membatasi perilaku oportunistic oleh manajer, yaitu manajer melaporkan laba secara oportunis untuk memaksimalkan kepentingan pribadinya. Pengawasan yang efektif dari investor institusional akan menekan terjadinya manipulasi keuangan oleh manajer yang akan berpengaruh pada laba perusahaan. Gambar 6 adalah data rata-rata kepemilikan institusional pada perusahaan manufaktur sub sektor industri barang konsumsi yang terdaftar di BEI periode 2012-2017.

Kepemilikan institusional pada perusahaan manufaktur sub sektor industri barang konsumsi yang terdaftar di BEI Indonesia periode 2012 -2017 cenderung meningkat. Kepemilikan institusional yang tinggi akan mempengaruhi manajer dalam pengambilan keputusan sehingga akan meningkatkan profitabilitas (Rafael \& Fehr, 2016), (Gugong et al., 2014), (Candradewi \& Sedana, 2016), dan (Widyati, 2013). Hipotesis yang diajukan adalah modal intelektual dan kepemilikan institusional berpengaruh terhadap profitabilitas, baik secara simultan maupun parsial, (2) profitabilitas berpengaruh terhadap nilai perusahaan.

\section{METODE}

Metode penelitian yang digunakan adalah metode kuantitatif dengan pendekatan penelitian deskriptif dan verifikatif, dengan menggunakan data sekunder yang bersumber dari www.idx.co.id dan situs resmi perusahaan yang dijadikan sampel. Pendekatan 
deskriptif digunakan untuk mengetahui kondisi modal intelektual, kepemilikan institusional, kinerja keuangan, dan nilai perusahaan pada perusahaan manufaktur sektor industri barang konsumsi yang terdaftar di Bursa Efek Indonesia (BEI) periode 2012-2017.

Metode penelitian verifikatif digunakan untuk mengetahui besarnya pengaruh modal intelektual dan kepemilikan institusional baik secara simultan maupun parsial terhadap kinerja keuangan dan besarnya pengaruh kinerja keuangan terhadap nilai perusahaan pada perusahaan manufaktur sektor industri barang konsumsi yang terdaftar di Bursa Efek Indonesia (BEI) periode 2012-2017. Operasionalisasi variabel ditunjukkan pada Tabel 1.

Jumlah populasi sebanyak 49 perusahaan yang termasuk sektor industri barang konsumsi dan terdaftar di Bursa Efek Indonesia. Teknik pengambilan sampel menggunakan purposive sampling, dengan kriteria: (1) Perusahaan manufaktur sektor industri barang konsumsi yang sudah terdaftar pada tahun 2012 dan sebelumnya yang masih terdaftar di Bursa Efek Indonesia atau tidak mengalami perpindahan sektor, (2) menerbitkan laporan keuangan per kuartal secara konsisten, (3) memiliki kepemilikan institusional secara konsisten, (4) tidak mengalami kerugian. Jumlah perusahaan yang memenuhi kriteria adalah 9 perusahaan. Hasil uji normalitas menunjukkan terdapat data 3 perusahaan yang merupakan outlier, sehingga data yang digunakan dari 6 perusahaan.

Data yang digunakan adalah data sekunder, yaitu berupa laporan keuangan diperoleh dari website Bursa Efek Indonesia melalui situs www.idx.co.id, www. idnfinancials.com, www.sahamok.com, Indonesian Capital Market Directory (ICMD), dan situs resmi perusahaan. Teknik analisis deskriptif menggunakan nilai rata-rata dari masing-masing variabel dan seluruh sampel yang diteliti untuk mengambil kesimpulan. Teknik analisis verifikatif yang digunakan adalah analisis regresi linier data panel.

\section{HASIL}

Hasil output perhitungan statistik terhadap 9 sampel pada perusahaan manufaktur sektor industri barang konsumsi yang terdaftar di Bursa Efek Indonesia periode 2012-2017 menunjukkan data yang tidak normal. Hal ini dikarenakan adanya data yang outlier yang perlu dikeluarkan. Hasilnya ada 6 perusahaan yang memenuhi syarat normalitas data. Tabel 2 menunjukkan hasil analisis statistik deskriptif. Modal intelektual yang dengan proksi value added intellectual capital diperoleh nilai mean sebesar 3,3416. Variabel kepemilikan institusional diperoleh nilai mean sebesar 0,6773. Variabel nilai perusahaan dengan proksi oleh price earning ratio diperoleh nilai mean sebesar 58,6148.

Hasil uji asumsi klasik menunjukkan bahwa data berdistribusi normal, tidak terjadi heteroskedastisitas, dan multikolinieritas pada data variabel independen.
Hasil analisis data persamaan 1 ditunjukkan pada Tabel 3. Pengaruh modal intelektual positif dan signifikan, sedangkan kepemilikan institusional positif dan tidak signifikan.

Persamaan regresi data panel untuk persamaan 1 adalah sebagai berikut:

$$
\mathrm{Y}=0,022+0,010 \mathrm{X}_{1}+0,007 \mathrm{X}_{2}+\mathrm{e}
$$

Pengaruh kinerja keuangan terhadap nilai perusahaan adalah positif dan signifikan. Persamaan regresi data panel untuk persamaan 2 adalah sebagai berikut:

$$
\mathrm{Z}=58,615+1,000 \mathrm{Y}_{1}+\mathrm{e} .
$$

Hasil uji koefisien determinasi simultan (Tabel 4) dapat diketahui bahwa nilai R-squared secara simultan yaitu sebesar 0,541. Berdasarkan perhitungan yang telah dilakukan dapat diketahui bahwa nilai koefisien determinasi parsial untuk modal intelektual memiliki kontribusi terhadap kinerja keuangan sebesar 54,534\%, sedangkan kontribusi kepemilikan institusional sebesar $-0,418 \%$. Berdasarkan Tabel 6 diketahui bahwa koefisien determinasi R-squared persamaan 2 sebesar 0,836 . Pengujian hipotesis simultan (Tabel 5) dapat diketahui bahwa modal intelektual dan kepemilikan institusional secara simultan berpengaruh signifikan terhadap kinerja perusahaan pada perusahaan manufaktur sub sektor industri barang konsumsi yang terdaftar di BEI periode 2012-2017.

\section{PEMBAHASAN}

Kondisi rata-rata modal intelektual pada perusahaan manufaktur sub sektor industri barang konsumsi yang terdaftar di BEI periode 2012-2017 cenderung menurun. Semakin tinggi modal intelektual menunjukkan semakin baik kinerja perusahaan karena mampu mengelola sekaligus mengembangkan sumber daya pengetahuan yang dimiliki sehingga dapat meningkatkan laba. Modal intelektual merupakan asset dan sumber daya tidak berwujud perusahaan, yaitu mencakup proses, kapasitas inovasi, pola, pengetahuan yang tidak kelihatan dari para anggotanya dan jaringan kolaborasi serta hubungan organisasi. Intellectual capital juga didefinisikan sebagai kombinasi dari sumber daya tidak berwujud dan kegiatan yang memungkinkan organisasi melakukan transformasi bahan, keuangan dan sumber daya manusia dalam sebuah sistem untuk menciptakan stakeholder value.

Kondisi rata-rata kepemilikan institusional cenderung tidak mengalami perubahan, karena tidak ada perubahan antara jumlah saham yang dimiliki oleh pihak institusi dengan jumlah saham yang beredar. Kepemilikan saham oleh institusi dapat dikatakan sebagai pihak eksternal yang menanamkan modalnya pada perusahaan serta berperan sebagai kontrol untuk melakukan pengawasan pada kinerja manajemen 
perusahaan selaku pihak yang menjalankan operasional perusahaan. Kepemilikan institusional yang tinggi dapat dikatakan bahwa investor memiliki kepercayaan dan keyakinan untuk menanamkan modalnya pada perusahaan tersebut.

Kondisi rata-rata kinerja keuangan cenderung meningkat. ROA tertinggi sebesar $8 \%$ dan terendah sebesar $6 \%$. ROA yang tinggi menunjukkan kinerja keuangan yang baik, berarti perusahaan berhasil memanfaatkan aset yang dimiliki untuk menghasilkan keuntungan. Penurunan kinerja terjadi karena pertumbuhan ekonomi Indonesia yang juga mengalami penurunan. Penurunan kinerja keuangan mempengaruhi juga minat investor.

Kondisi nilai perusahaan yang diukur dengan PER memiliki kecenderungan menurun, tertinggi sebesar 52,02x dan terendah 43,73x. Semakin tinggi PER menunjukkan bahwa investor mempunyai harapan yang baik terhadap perkembangan perusahaan di masa datang, sehingga untuk EPS tertentu, investor bersedia membayar dengan harga yang lebih mahal. PER suatu saham memiliki nilai tinggi atau rendah, harus membandingkan dengan sektor industri sejenis. PER bisa dikatakan rendah apabila PER berada di bawah PER industri, dan sebaliknya PER bisa dikatakan tinggi apabila PER berada di atas PER industri sejenis.

Modal intelektual dan kepemilikan institusional secara simultan berpengaruh signifikan terhadap kinerja keuangan sebesar 54,10\%. Modal intelektual memiliki pengaruh sebesar 54,53\% dan kepemilikan institusional sebesar $-0,418 \%$. Modal intelektual memiliki pengaruh positif dan signifikan terhadap kinerja keuangan, membuktikan knowledge based theory, yaitu apabila perusahaan dapat mengelola sekaligus mengembangkan sumber daya pengetahuan yang dimiliki maka dapat meningkatkan laba, sedangkan kepemilikan institusional memiliki pengaruh positif dana tidak signifikan.

Hasil penelitian ini sejalan dengan penelitian (Nuryaman, 2015), (Yovita \& Amrania, 2018), (Marzban et al., 2014), (Darabi et al., 2012), (Parast, Lella Zarat Dakhely; Delkhak, 2013), (Baroroh, 2013), (Agustina et al., 2015), (Yulandari \& Gunawan, 2019), dan (Nurhayati, 2017), bahwa modal intelektual berpengaruh signifikan terhadap kinerja keuangan, yaitu profitabilitas. Hasil ini mendukung knowledgebased economy yang menunjukkan bahwa pemanfaatan modal intelektual secara efisien dan efektif, dapat meningkatkan profitabilitas, yang selanjutnya dapat meningkatkan nilai perusahaan. Pengetahuan adalah sumber daya yang dapat digunakan untuk meningkatkan kinerja perusahaan. Modal intelektual menjadi lebih penting dibandingkan dengan faktor produksi lainnya.

Kepemilikan institusional tidak memiliki pengaruh signifikan terhadap profitabilitas, berarti komposisi kepemilikan tidak mempengaruhi pengambil keputusan dalam menghasilkan laba. Hasil ini sejalan dengan penelitian (Hikmah and Fitria, 2019), (Abeyrathna \& Ishari, 2016), (Puniayasa \& Triaryati, 2016), (Rahman
\& Reja, 2015), dan (Wiranata \& Nugrahanti, 2013). namun bertentangan dengan (Rafael \& Fehr, 2016), (Gugong et al., 2014), (Noviawan \& Septiani, 2013), dan (Widyati, 2013). Kepemilikan institusional tidak berhasil mempengaruhi kebijakan manajemen untuk memperoleh kinerja yang lebih baik pada perusahaan manufaktur sub sektor industri barang konsumsi yang terdaftar di BEI periode 2012-2017.

Kinerja keuangan dengan proksi ROA memiliki pengaruh terhadap nilai perusahaan sebesar $83,60 \%$. Informasi kinerja perusahaan terutama profitabilitas diperlukan untuk menilai perubahan potensial di masa datang. Informasi kinerja juga bermanfaat untuk memprediksi kapasitas perusahaan dalam menghasilkan arus kas dari sumber daya yang ada, serta berguna dalam perumusan perimbangan tentang efektivitas perusahaan dalam memanfaatkan sumber daya. Hasil penelitian ini sejalan dengan teori, bahwa semakin besar nilai profitabilitas menunjukkan perusahaan beroperasi dengan efisien, biaya yang dikeluarkan semakin rendah, dan laba semakin tinggi, tingkat kepercayaan investor semakin tinggi, sehingga harga saham meningkat yang akan meningkatkan PER perusahaan (Ramadhani et al., 2019). Hasil penelitian ini sejalan dengan penelitian (Nopiani, Kadek Dian; Sulindawati, Luh Gede Erni; Sujana, 2015), (Wahyuningsih \& Widowati, 2016), (Hayati, 2010), dan (Ahmadi, 2019) yang menunjukkan bahwa kinerja keuangan berpengaruh positif dan signifikan terhadap nilai perusahaan.

\section{KESIMPULAN}

Kondisi rata-rata modal intelektual dan nilai perusahaan pada perusahaan manufaktur sub sektor industri barang konsumsi yang terdaftar di BEI periode 2012-2017 cenderung menurun. Kondisi rata-rata kepemilikan institusional cenderung tidak mengalami perubahan. Kondisi rata-rata kinerja keuangan cenderung meningkat. Modal intelektual dan kepemilikan institusional secara simultan berpengaruh terhadap kinerja keuangan. Modal intelektual memiliki pengaruh positif dan signifikan terhadap kinerja keuangan secara parsial. Kepemilikan institusional tidak memiliki pengaruh signifikan. Kinerja keuangan memiliki pengaruh signifikan terhadap nilai perusahaan. Modal intelektual memiliki peran penting untuk meningkatkan kinerja keuangan dan nilai perusahaan.

\section{DAFTAR PUSTAKA}

Abeyrathna, G. M., \& Ishari, S. 2016. Impact of Ownership Structure on Firms' Performance of Manufacturing Companies in Sri Lanka. International Journal of Scientific and Research Publications, 6(10), 111.

Agustina, W., Yuniarta, G. A., \& Sinarwati, N. K. 2015. Pengaruh Intellectual Capital, Corporate 
Governance dan Corporate Social Responsibility Terhadap Kinerja Keuangan. e-Journal Akuntansi Universitas Pendidikan Ganesha, 3(1), 1-11.

Ahmadi, N. B. R. 2019. Pengaruh Return On Assets (ROA), Return On Equity (ROE), Net Profit Margin (NPM), dan Gross Profit Margin (GPM) Terhadap Harga Saham Perbankan Syariah Periode Tahun 2014 - 2018. KITABAH, 3(2), 110-121.

Baroroh, N. 2013. Analisis Pengaruh Modal Intelektual Terhadap Kinerja Keuangan Perusahaan Manufaktur Di Indonesia. Jurnal Dinamika Akuntansi, 5(2), 172-182. https://doi.org/10.15294/jda.v5i2.2997

Brigham, E. F., \& Houston, J. F. 2019. Fundamentals of Financial Management 15 Edition. Cengage Learning.

Candradewi, I., \& Sedana, I. 2016. Pengaruh Kepemilikan Manajerial, Kepemilikan Institusional Dan Dewan Komisaris Independen Terhadap Return on Asset. E-Jurnal Manajemen Universitas Udayana, 5(5), 255207.

Darabi, R., Kamran Rad, S., \& Ghadiri, M. 2012. The relationship between intellectual capital and earnings quality. Research Journal of Applied Sciences, Engineering and Technology, 4(20), 4192-4199.

Diaz, R., \& Jufrizen. 2014. Pengaruh Return on Assets [ROA] dan Return On Equity (ROE) pada Perusahaan Asuransi yang Terdaftar di Bursa Efek Indonesia. Jurnal Manajemen dan Bisnis, 02, 127134. https://doi.org/10.1007/0-387-26336-5_1736

Fahmi, I. 2015. Pengantar Manajemen Keuangan: Teori dan Soal Jawab. Alfabeta.

Gitman, Lawrence J. and Zutter, C. J. 2015. Principle of Management Finance (Fourteen). Pearson Education Limited.

Gugong, B. K., Arugu, L. O., \& Dandago, K. I. 2014. The Impact of Ownership Structure on the Financial Performance of Listed Insurance Firms in Nigeria. International Journal of Academic Research in Accounting, Finance and Management Sciences, 4(1), 409-416. https://doi.org/10.6007/ijarafms/ $v 4-i 1 / 698$

Hartono, J. 2015. Teori Portfolio dan Analisis Investasi (10th ed).

Hayati, N. 2010. Faktor-faktor yag Mempengaruhi Price Earning Ratio (PER) sebagai Salah Satu Kriteria Keputusan Investasi Saham Perusahaan Real Estate dan Property di Bursa Efek Indonesia. Jurnal Manajemen dan Akuntansi, 11(1), 53-62.

Hikmah and Fitria, N. L. 2019. The Effect of Managerial Ownership, Institutional Ownership, and Independent Board of Commissioners on Return On Assets (Study in Bnaking Companies Listed in The Indonesia Stock Exchange 2013 - 2017). IOSR Journal of Economics andFinance, 10(4), 43-48. https://doi.org/10.14414/tiar.v9i1.1631

Kasmir. 2015. Analisis Laporan Keuangan. PT. Raja Grafindo Persada.
Marzban, H. A., Poor, V. K., Kasgari, D. R., \& Amini, A. 2014. The Relationship Between Intellectual Capital and Earnings Quality Indicators in Emerging Companies Listed in Tehran Stock Exchange. Indian journal of Fundamental and Apploed Life Science, 4(S1), 985-995. https://doi.org/10.1016/j. sbspro.2012.03.227

Nopiani, Kadek Dian; Sulindawati, Luh Gede Erni; Sujana, E. 2015. Pengaruh Mekanisme Corporate Governance Terhadap Kinerja Keuangan Bank Perkreditan Rakyat di Bali. Jurnal Akuntansi Program S1, 3(1). https://doi.org/10.21002/ jaki.2010.11

Noviawan, R. A., \& Septiani, A. 2013. Pengaruh Mekanisme Corporate Governance Dan Struktur Kepemilikan Terhadap Kinerja Keuangan. Diponegoro Journal of Accounting, 2(3), 744-753.

Nurhayati, S. 2017. Analisa Pengaruh Intellectual Capital Terhadap Kinerja Pasar Dan Kinerja Keuangan Pada Perusahaan Lq45 Yang Terdaftar Di Bursa Efek Indonesia Periode Tahun 2010-2013. Jurnal ASET (Akuntansi Riset), 9(1), 133. https:// doi.org/10.17509/jaset.v9i1.5260

Nuryaman. 2015. The Influence of Intellectual Capital on The Firm's Value with The Financial Performance as Intervening Variable. Procedia - Social and Behavioral Sciences, 211(September), 292-298. https://doi.org/10.1016/j.sbspro.2015.11.037

Parast, Lella Zarat Dakhely; Delkhak, J. J. E. 2013. The Study of Intellectual Capital and Earnings in the Tehran Stock Exchange. European Online Journal of Natural and Social Sciences, 2(3).

Puniayasa, I., \& Triaryati, N. 2016. Pengaruh Good Corporate Governance, Struktur Kepemilikan Dan Modal Intelektual Terhadap Kinerja Keuangan Perusahaan Yang Masuk Dalam Indeks Cgpi. E-Jurnal Manajemen Universitas Udayana, 5(8), 254914.

Rafael, A., \& Fehr, E. 2016. Institutional ownership and performance: An Overview in emerging and developed countries. Master Thesis. 1-38.

Rahman, A. N. A. A., \& Reja, B. A. F. M. 2015. Ownership Structure and Bank Performance. Journal of Economics, Business and Management, 3(5), 483-488. https://doi.org/10.7763/joebm.2015. v3.232

Ramadhani, G., Kamaliah, \& Silfi, A. 2019. Analisis Faktor-Faktor Yang Mempengaruhi Price Earning Ratio Pada Perusahaan Manufaktur Yang Terdaftar Di Bursa Efek Indonesia 2007-2011. Jurnal Ilmiah Riset Akuntansi, 53(9), 1689-1699.

Tandelilin, E. 2010. Portofolio dan Investasi: Teori dan aplikasi. Kanisius.

Wahyuningsih, P., \& Widowati, M. 2016. Analisis ROA dan ROE Terhadap Nilai Perusahaan dengan Corporate Social Responsibility sebagai Variabel Moderating. STIE Semarang, 8(3), 83-102. 
Widyati, M. F. 2013. Pengaruh Dewan Direksi, Komisaris Independen, Komite Audit, Kepemilikan Manajerial dan Kepemilikan Institusional Terhadap Kinerja Keuangan. Jurnal Ilmu Manajemen (JIM), 1(1).

Wiranata, Y. A., \& Nugrahanti, Y. W. 2013. Pengaruh Struktur Kepemilikan Terhadap Profitabilitas Perusahaan Manufaktur di Indonesia. Jurnal Akuntansi dan Keuangan, 15(1), 15-26. https:// doi.org/10.9744/jak.15.1.15-26

Yovita, M., \& Amrania, G. K. P. 2018. The Influence of Intellectual Capital to Market Value with Return on Assets as Intervening Variable. Journal of Accounting Auditing and Business, 1(2), 7. https:// doi.org/10.24198/jaab.v1i2.18267

Yulandari, L. F., \& Gunawan, H. 2019. Pengaruh Intellectual Capital Terhadap Nilai Pasar Dan Kinerja Keuangan Perusahaan Yang Terdaftar Di Bursa Efek Indonesia. Journal of Applied Managerial Accounting, 3(1), 36-50. https://doi. org/10.30871/jama.v3i1.938

Tabel 1. Operasionalisasi Variabel

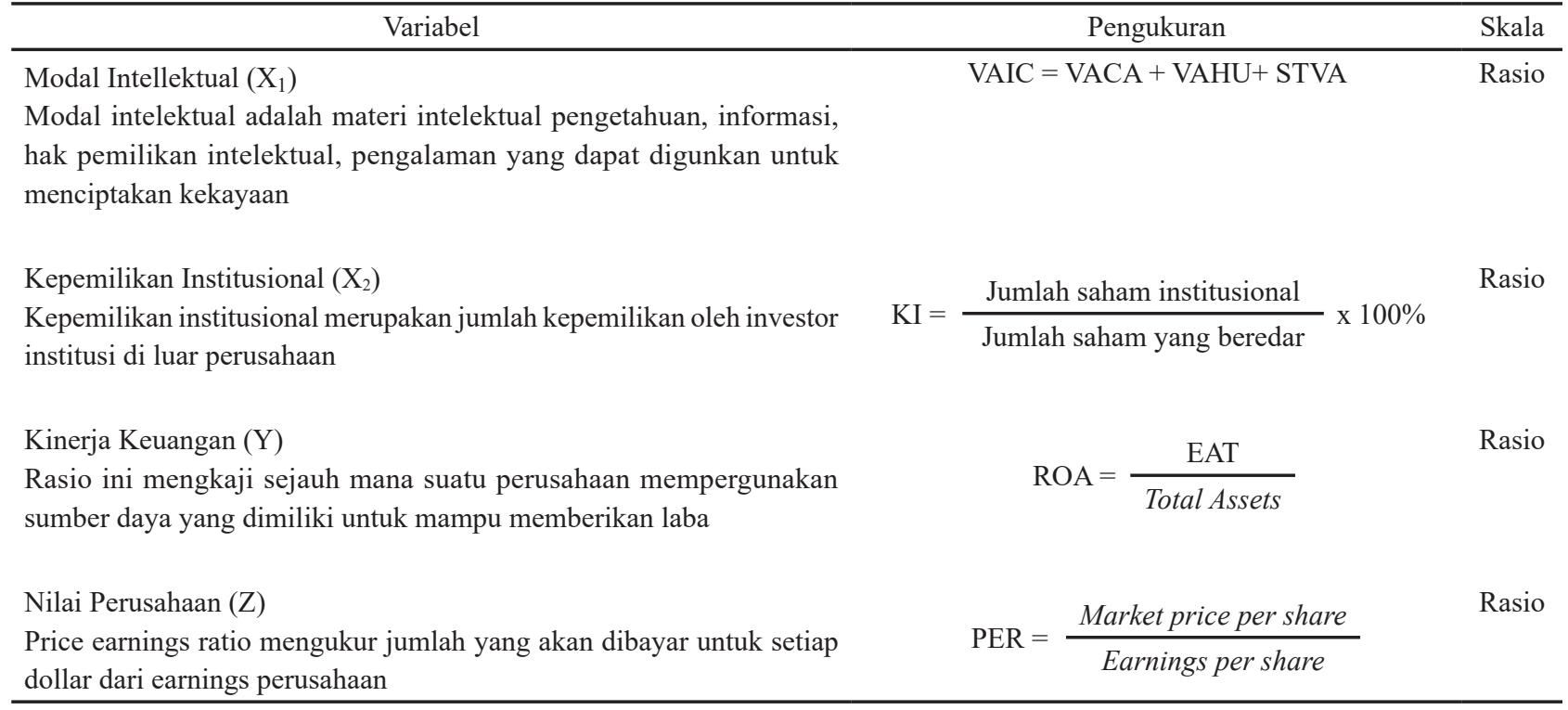

Tabel 2. Statistika Desktiptif

\begin{tabular}{lcccc}
\hline & NP_PER & KK_ROA & $\mathrm{X}_{1}$ Modal Intelektual & $\mathrm{X}_{2}$ KEP. Institusional \\
\hline Mean & 58,6148 & 0,0597 & 3,3416 & 0,6773 \\
Maximum & 158,81 & 0,10 & 5,67 & 0,90 \\
Minimum & 23,49 & 0,02 & 0,04 & 0,33 \\
Std. Dev. & 31,03649 & 0,01746 & 1,33380 & 0,17994 \\
Skewness & 1,583 & $-0,118$ & $-0,235$ & $-0,719$ \\
Kurtosis & 2,206 & 0,341 & $-0,541$ & $-0,687$ \\
Probability & 0,011 & 0,727 & 0,669 & 0,095 \\
Sum & 2110,13 & 2,15 & 120,30 & 24,38 \\
Observations & 36 & 36 & 36 & 36 \\
\hline Sumber: Hasil Statistika Deskriptif dengan SPSS 20 &
\end{tabular}

Sumber: Hasil Statistika Deskriptif dengan SPSS 20

Tabel 3. Analisis Regresi Persamaan 1

Coefficients $^{a}$

\begin{tabular}{|c|c|c|c|c|c|c|c|c|c|}
\hline \multirow[b]{2}{*}{ Model } & & \multicolumn{2}{|c|}{$\begin{array}{c}\text { Unstandardized } \\
\text { Coefficients }\end{array}$} & \multirow{2}{*}{$\begin{array}{c}\text { Standardized } \\
\text { Coefficients } \\
\text { Beta }\end{array}$} & \multirow[b]{2}{*}{ t } & \multirow[b]{2}{*}{ Sig. } & \multicolumn{2}{|c|}{ Correlations } & \multirow[b]{2}{*}{ Part } \\
\hline & & $B$ & Std. Error & & & & Zero-order & Partial & \\
\hline \multirow[t]{3}{*}{1} & (Constant) & ,022 &, 010 & & 2,129 &, 041 & & & \\
\hline & $\mathrm{X}_{1}$ Modal Intelektual & ,010 & ,002 & ,745 & 6,223 &, 000 & ,732 &, 735 & ,734 \\
\hline & $\mathrm{X}_{2}$ Kep. Institusional & ,007 & ,012 & ,076 & ,636 &, 529 &,- 055 &, 110 & ,075 \\
\hline
\end{tabular}

a. Dependent Variable: KK_ROA 
Tabel 3. Hasil Regresi untuk Persamaan 2

Coefficients $^{a}$

\begin{tabular}{|c|c|c|c|c|c|c|c|c|c|}
\hline \multirow[b]{2}{*}{ Model } & & \multicolumn{2}{|c|}{$\begin{array}{c}\text { Unstandardized } \\
\text { Coefficients }\end{array}$} & \multirow{2}{*}{$\begin{array}{c}\begin{array}{c}\text { Standardized } \\
\text { Coefficients }\end{array} \\
\text { Beta }\end{array}$} & \multirow[b]{2}{*}{$t$} & \multirow[b]{2}{*}{ Sig. } & \multicolumn{3}{|c|}{ Correlations } \\
\hline & & $B$ & Std. Error & & & & Zero-order & Partial & Part \\
\hline 1 & (Constant) & 58,615 & 2,128 & & 27,545 & 000 & & & \\
\hline & Unstandardized Residual & 1,000 &, 076 & ,914 & 13,146 &, 000 & ,914 & ,914 & ,914 \\
\hline
\end{tabular}

a. Dependent Variable: NP_PER

Tabel 4. Hasil Uji Koefisien Determinasi Simultan

\begin{tabular}{lccccc}
\hline Model & $R$ & $R$ Square & Adjusted R Square & Std. Error of the Estimate & Durbin-Watson \\
\hline 1 &, $736^{\mathrm{a}}$ &, 541 &, 514 &, 01218 & 2,296 \\
\hline a. Predictors: (Constant), $\mathrm{X}_{2}$ Kep. Institusional, $\mathrm{X}_{1}$ Modal Intelektual \\
b. Dependent Variable: KK_ROA
\end{tabular}

Tabel 5. Hasil Uji Koefisien Determinasi Parsial untuk Persamaan 2 Model Summary ${ }^{b}$

\begin{tabular}{ccccc}
\hline Model & $R$ & $R$ Square & Adjusted $R$ Square & Std. Error of the Estimate \\
\hline 1 &, $914^{\mathrm{a}}$ &, 836 &, 831 & 12,76788 \\
\hline
\end{tabular}

a. Predictors: (Constant), Unstandardized Residual

b. Dependent Variable: NP_PER

Tabel 6. Hasil Uji Simultan (Uji F)

ANOVAa

\begin{tabular}{llccccc}
\hline Model & & Sum of Squares & Df & Mean Square & $F$ & Sig. \\
\hline 1 & Regression &, 006 & 2 &, 003 & 19,475 &, $000^{\mathrm{b}}$ \\
& Residual &, 005 & 33 &, 000 & & \\
& Total &, 011 & 35 & & & \\
\hline
\end{tabular}

a. Dependent Variable: KK_ROA

b. Predictors: (Constant)

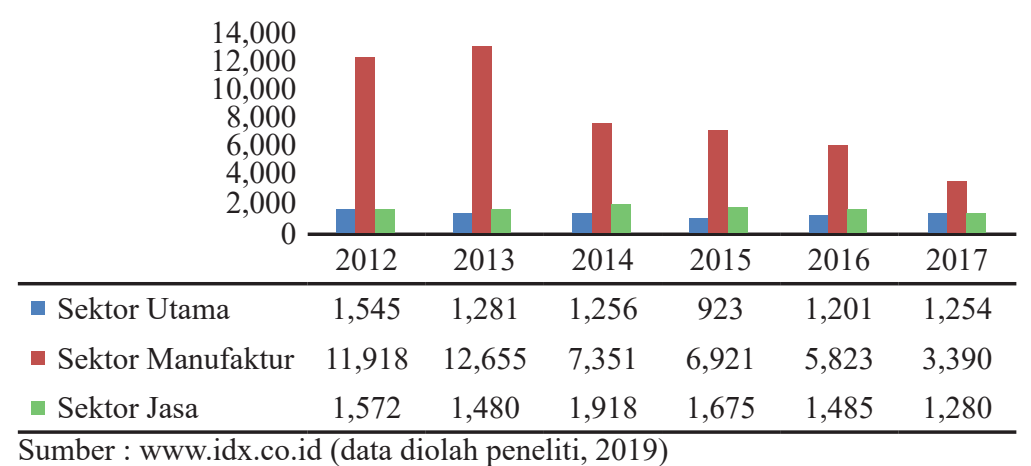

Sumber : www.idx.co.id (data diolah peneliti, 2019)

Gambar 1. Perkembangan Harga Saham 3 Sektor Nasional di BEI Tahun 2012 - 2017 


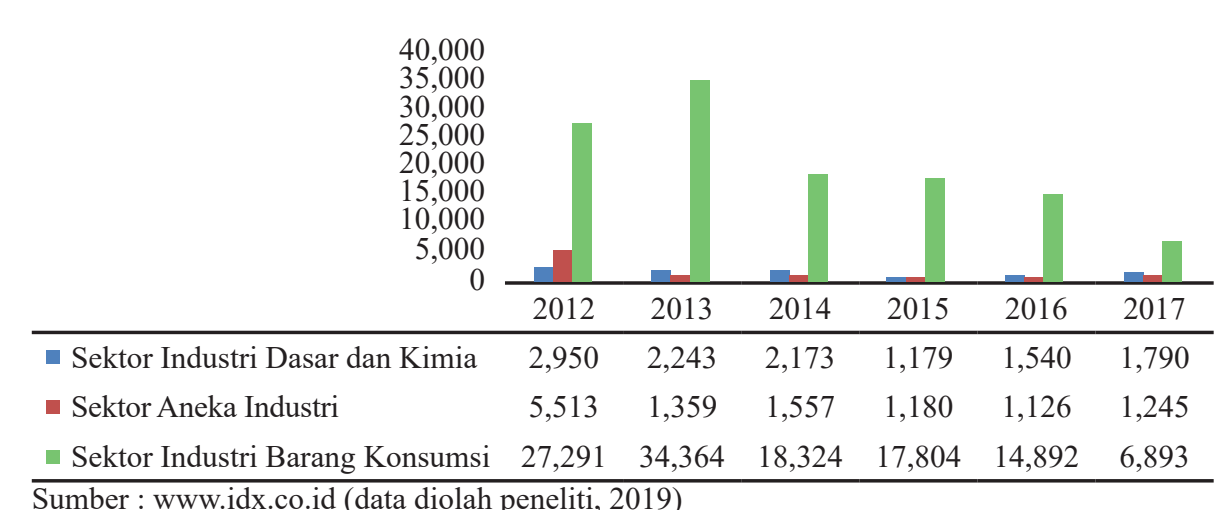

Sumber : www.idx.co.id (data diolah peneliti, 2019)

Gambar 2. Perkembangan Harga Saham Per Sektor Manufaktur di BEI Tahun 2012 - 2017

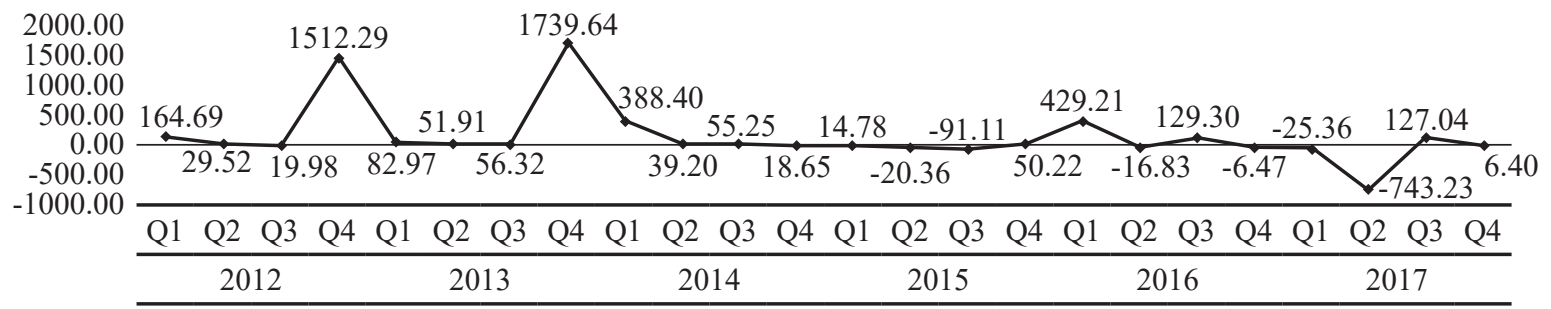

Sumber : www.idx.co.id (data diolah peneliti, 2019)

Gambar 3. Rata-rata PER Perusahaan Sub Sektor Barang Konsumsi di BEI Tahun 2012 - 2017

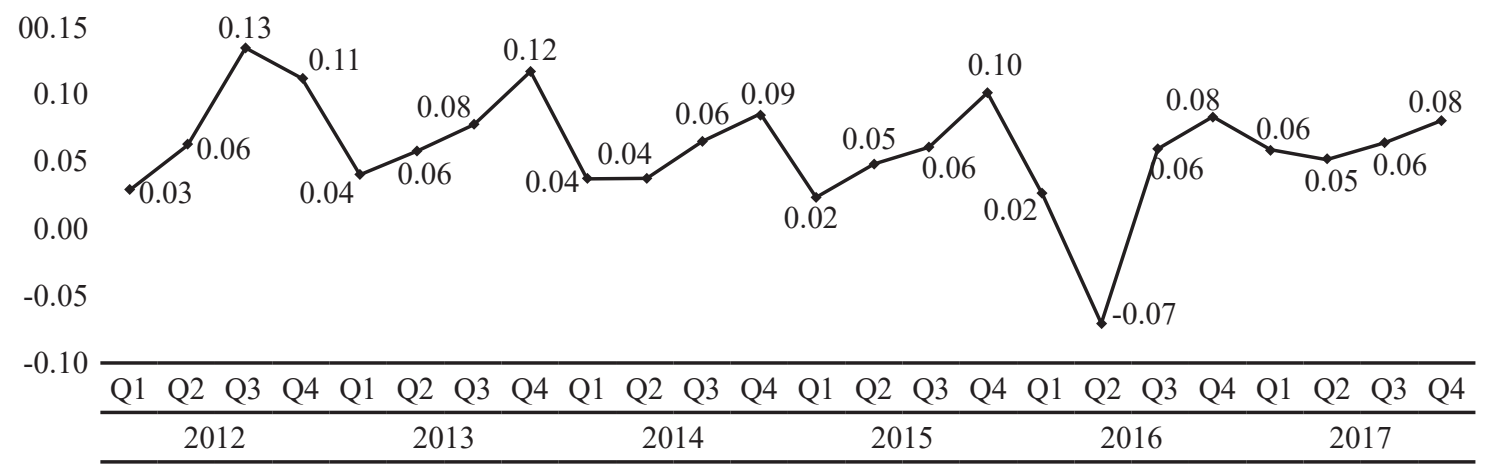

Sumber : www.idx.co.id (data diolah peneliti, 2019)

Gambar 4. Perkembangan ROA Perusahaan Manufaktur Sub Sektor Barang Konsumsi di BEI Tahun $2012-2017$

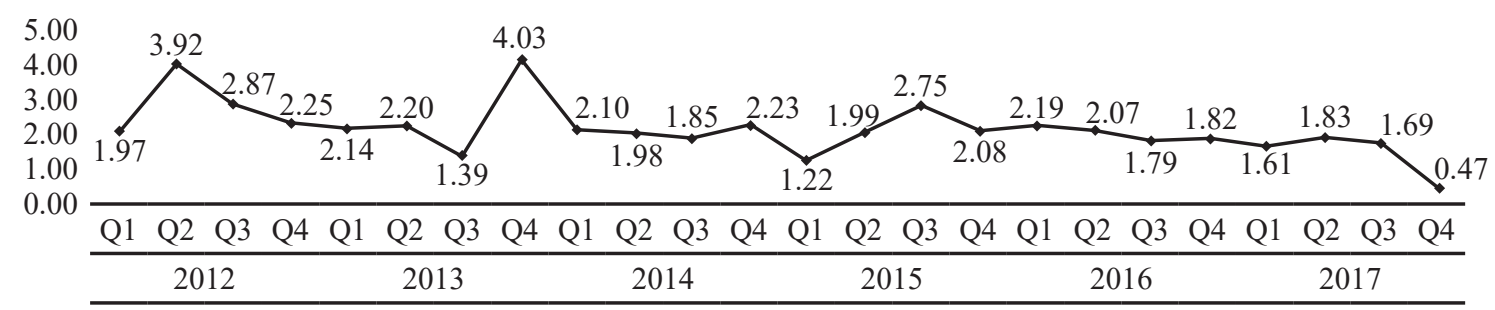

Sumber : www.idx.co.id (data diolah peneliti, 2019)

Gambar 5. Perkembangan VAIC ${ }^{\mathrm{TM}}$ Perusahaan Manufaktur Sub Sektor Barang Konsumsi di BEI Tahun $2012-2017$ 
80.00

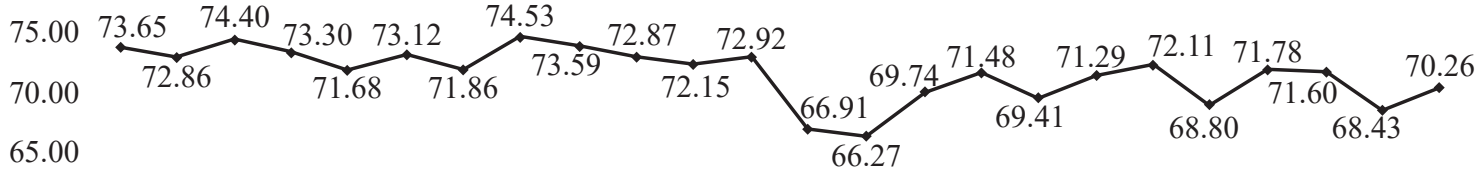

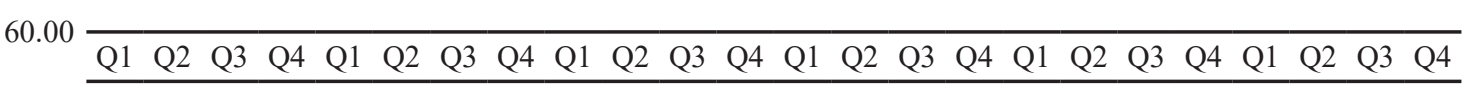

$\frac{2013}{\text { Sumber : www.idx.co.id (data diolah peneliti, 2019) }}$

Gambar 6. Perkembangan Kepemilikan Institusional Pada Perusahaan Manufaktur Sub Sektor Barang Konsumsi di BEI Tahun 2012 - 2017 